\title{
Partial hepatectomy induces delayed hepatocyte proliferation and normal liver regeneration in ovariectomized mice
}

This article was published in the following Dove Press journal:

Clinical and Experimental Gastroenterology

2 July 2015

Number of times this article has been viewed

\author{
Makoto Umeda' \\ Masaki Hiramoto ${ }^{1,2}$ \\ Takeshi Imai' \\ 'Department of Aging Intervention, \\ National Center for Geriatrics \\ and Gerontology, Obu, Aichi, Japan; \\ ${ }^{2}$ Department of Biochemistry, Tokyo \\ Medical University, Tokyo, Japan
}

\begin{abstract}
Estrogens play central roles in sexual development, reproduction, and hepatocyte proliferation. The ovaries are one of the main organs for estradiol (E2) production. Ovariectomies (OVXs) were performed on the female mice, and hepatocyte proliferation was analyzed. The ovariectomized mice exhibited delayed hepatocyte proliferation after partial hepatectomy $(\mathrm{PH})$ and also exhibited delayed and reduced E2 induction. Both E2 administration and PH induced the gene expression of estrogen receptor $\alpha(E R \alpha)$. The transcripts of $E R \alpha$ were detected specifically in periportal hepatocytes after E2 administration and $\mathrm{PH}$. Moreover, the E2 concentrations and hepatocyte proliferation rates were highest in the proestrus period of the estrous cycle. Taken together, these findings indicate that E2 accelerated ER $\alpha$ expression in periportal hepatocytes and hepatocyte proliferation in the female mice.
\end{abstract}

Keywords: estrogen, ER, estrous cycle, hepatocyte proliferation, liver regeneration

\section{Introduction}

Estrogens have a number of functions in development, growth, and sex differentiation, and they play important roles in female reproduction and in nonreproductive tract tissues, including the gonads, brain, bone, adipose tissue, and cardiovascular system. ${ }^{1,2}$ Estrogens contain mainly three compounds; Estron (E1), Estradiol (E2), and Estriol (E3). E2 is most active hormone among these Estrogens. The target factors of estrogens are thought to consist of three proteins, the estrogen receptor $\alpha(E R \alpha)$, estrogen receptor $\beta$ (ER $\beta$ ), and the G protein-coupled receptor 30 (GPR30). ${ }^{3-6}$

Several studies have implicated the liver as an estrogenic organ, and an ER activity ${ }^{7}$ (later called genomic reaction) has been detected in this organ before the first ER (later named ER $\alpha$ ) was cloned from MCF7 (Michigan Cancer Foundation 7), human mammary cell line. ${ }^{7-13}$

The liver plays a pivotal role in mammalian homeostasis and has the ability to complement its original mass in response to several types of stress, including partial hepatectomy (PH). ${ }^{14,15}$ After $\mathrm{PH}$, hepatocytes proliferate intensely for a few days, and the liver regenerates in 2 weeks. ${ }^{14,15}$

Estrogens induce hepatocyte proliferation in vitro in neonate and in vivo after PH. ${ }^{8,11,12}$ These multiple effects could be mediated by ER $\alpha$ rather than ER $\beta$ and GPR30 because ER $\alpha$ has been shown to be expressed in the mouse liver. ${ }^{16-18}$ Moreover, estradiol (E2) signaling in the liver is a genomic reaction (see above), which indicates that $\mathrm{ER} \alpha$ and/or ER $\beta$ are targets for E2 signaling in the liver. ${ }^{17,18}$ The expression of ER $\beta$ has not been detected in the liver, but ER $\alpha$ transcripts were detected. ${ }^{19}$ Taken together, the target factor of E2 in the liver may be ER $\alpha{ }^{20}$
Correspondence: Takeshi Imai Department of Aging Intervention, National Center for Geriatrics and Gerontology, Obu, Aichi 474-85II, Japan Tel +8 I 5624623 II

Fax +8I 562468397

Email dai.ncgg@gmail.com 
To elucidate estrogen signaling in the liver of the female mice, ovariectomies (OVXs) were first performed to decrease E2 production, because the ovary is the tissue that produces the most E2. ${ }^{21,22}$ Next, the female mice were treated with E2. We showed that circulating E2 is significantly increased after $\mathrm{PH}$ in both non-OVX and OVX female mice and demonstrated that $\mathrm{ER} \alpha$, the expression of which is enhanced by $\mathrm{E} 2$ administration, plays a crucial role in E2-induced hepatocyte proliferation and liver regeneration.

\section{Materials and methods \\ Materials}

$\beta$-Estradiol (052-04041; Wako Pure Chemical Industries, Ltd, Osaka, Japan), 4-hydroxytamoxifen (H7904; SigmaAldrich, St Louis, MO, USA), and ICI182780 (ICI, I4409; Sigma-Aldrich) were purchased. The E2 enzyme immunoassay kit (No 582251) was purchased from Funakoshi (Tokyo, Japan). EDTA (15111-45), NaCl (31320-34), and Tris (35406-91) were purchased from Nacalai Tesque, Inc. (Kyoto, Japan). ER $\alpha$-specific agonist 4,4', 4' -(4-propyl-[1H]pyrazole-1,3,5-triyl)trisphenol (PPT, CAS No: 263717-53-9) was purchased from Sigma-Aldrich (H6036). ER $\beta$-specific agonist 2,3-bis(4-hydroxyphenyl)propionitrile (DPN) was purchased from Cayman Chemical, Ann Arbor, MI, USA/ Funakoshi 10008842. The Hep G2 cell line from human hepatocellular carcinoma cell line was purchased from the American Type Culture Collection (HB-8065; ATCC, Manassas, VA, USA).

\section{Hepatocyte proliferation in the female mice}

The hepatocyte proliferation rates of the female mice were analyzed with bromodeoxyuridine (BrdU, M0744; Dako Denmark A/S, Glostrup, Denmark) immunohistochemistry (IHC, SK-4105; Vector Marketing Corporation, Gibbsboro, NJ, USA). The females were injected intraperitoneally with $50 \mathrm{mg} / \mathrm{kg}$ of BrdU 2 hours before dissection, and the livers were removed, rinsed, and embedded in the tissue-Tek OCT compound (Sakura Finetek Japan Co, Ltd, Tokyo, Japan). Ten-micrometer cryosections were fixed with 4\% paraformaldehyde, incubated with an antibody against BrdU (No 11170376001, Hoffman-La Roche Ltd, Basel, Switzerland) that was diluted 50 -fold in $0.1 \%$ bovine serum albumin/phosphate-buffered saline (BSA/PBS), revealed by CY3-conjugated donkey anti-rabbit IgG antibody, and mounted with Vectashield medium (Vector Laboratories Ltd, Burlingame, CA, USA). The numbers of BrdUpositive hepatocyte nuclei in at least five low-magnification microscopic fields of each sample ( 2000 hepatocytes) were counted..$^{23-25}$

\section{In situ hybridization}

The RNA probes were prepared. The ER $\alpha$ and ER $\beta$ cDNAs were cloned into pSG5 vector, ${ }^{26}$ and the ${ }^{35}$ S-labeled antisense probes were synthesized by $\mathrm{T} 7$ in vitro transcription and translation system (Promega Corporation, Fitchburg, WI, USA). The specimens were prehybridized for 2 hours at $50^{\circ} \mathrm{C}$ in prehybridization buffer $(50 \%$ formamide, $0.3 \mathrm{M} \mathrm{NaCl}, 10 \mathrm{mM}$ Tris- $\mathrm{HCl}$ at $\mathrm{pH} 6.8,10 \mathrm{mM} \mathrm{NaPO}_{4}$ at $\mathrm{pH}$ 6.8, 5 mM Ethylenediaminetetraacetic aicd (EDTA), $1 \times$ Denhart's, 10 mM DTT, $500 \mathrm{mg} / \mathrm{mL}$ yeast RNA, $100 \mathrm{mg} / \mathrm{mL}$ salmon sperm DNA, and $500 \mathrm{nmol} / \mathrm{mL}$ nonlabeled $\alpha$-thio-UTP [DuPont, Wilmington, DE, USA]). After the RNase A treatment, the slides were washed for 1 hour in the washing buffer $(50 \%$ formamide, $0.3 \mathrm{M} \mathrm{NaCl}, 10 \mathrm{mM}$ Tris- $\mathrm{HCl}$ at $\mathrm{pH} 6.8,10 \mathrm{mM} \mathrm{NaPO}_{4}$ at $\mathrm{pH}$ 6.8, 5 mM EDTA, 1×Denhart's, and $10 \mathrm{mM}$ DTT). The slides were subsequently washed in $2 \times$ Saline-Sodium Citrate buffer (SSC) for 15 minutes at room temperature, in $0.1 \times \mathrm{SSC}$ for 15 minutes at $50^{\circ} \mathrm{C}$, and then in $0.1 \times \mathrm{SSC}$ for 30 minutes at room temperature. After dehydration of the sections, they were coated with Kodak NTB-2 emulsion, dried, and stored at $4^{\circ} \mathrm{C}$. The exposure time ranged from 12 days to 15 days. Kodak D19 developer was used for 2 minutes at room temperature. The sections were then stained in toluidine blue, dehydrated in ethanol, and mounted under coverslips in Eukitt mounting medium. ${ }^{26-29}$

\section{Reverse transcription polymerase chain reaction}

Total liver RNA was extracted by the guanidium thiocyanatephenol-chloroform method. cDNA was synthesized for 20 minutes at $50^{\circ} \mathrm{C}$ from $1 \mu \mathrm{g}$ of RNA with Moloney murine leukemia virus reverse transcriptase. The transcribed cDNA was amplified by 30 cycles of PCR for ER $\alpha$ ( $5^{\prime}$-CGG CTG CCA CTT ACC TGG GAG CTC TCA GAT- $3^{\prime}$ and $5^{\prime}$-GGG GAG CCT GGG AGC TCT CAG AT-3'), ER $\beta$ (5'-TCT CTG AGA GCA TCATGT CC-3' and 5'-CAG CCT GGC CGT CAC TGT GA-3'), and hypoxanthine phosphoribosyltransferase (5'-GTA ATG ATC AGT CAA CGG GGG AC-3' and 5'-CCA GCA AGC TTG CAA CCT TAA CCA-3'). ${ }^{24,30,31}$

\section{Surgeries (PHs, orchiectomies, and OVXs)}

Liver resection of the left and median lobes was performed following midventral laparotomy between 8 am and 11 am under isoflurane anesthesia as previously described. ${ }^{23,32}$ The 
bilateral OVX procedure was performed as follows: the mice were anesthetized with peritoneal injections of pentobarbital, one central lateral incision was made in the skin, and two lateral incisions were made in the muscle layer, and the ovaries were extracted through the incision and excised after ligation.

\section{Animal study compliance}

All experiments were performed in accordance with the ethical guidelines for animal care of the National Center for Geriatrics and Gerontology (NCGG). The experimental protocols were approved by the Animal Care Committee of the NCGG. All the surgeries were performed under sodium pentobarbital anesthesia, and all efforts were made to minimize the suffering of the animals. E2 injections were decreased from five repetitions to a single injection to decrease the suffering of the sacrificed and operated mice.

\section{Hep G2 cell culture}

Hep G2 cells from a human liver carcinoma were maintained in $\alpha$-minimal essential medium (11900-073; Thermo Fisher Scientific, Waltham, MA, USA) supplemented with 10\% fetal calf serum (FCS, CC3008-504, Cell Culture Technology, Tokyo, Japan). The cells were plated at a density of $1.5-3 \times 10^{6}$ cells/60-mm dish, and after 48 hours, the culture medium was exchanged for $\alpha$-minimal essential medium without phenol red supplemented with $0.5 \%$ charcoal-treated FCS. After 24 hours, the cells were treated with $\beta$-estradiol or an equal volume $(0.01$ $[\mathrm{v} / \mathrm{v}] \%$ ) of vehicle (EtOH, 14712-34; Nacalai Tesque, Inc.). ${ }^{20,25}$ Phenol red is a known phytoestrogen. The FCS contains higher endogenous estrogen concentrations, and the charcoal treatment reduces this concentration in the FCS.

\section{Statistical analysis}

The values are reported as the mean \pm SEM. Statistical significance (ANOVA and Student's $t$-test) is indicated as follows: $* P<0.05 ; * * P<0.005 ; * * * P<0.0001$. Nonsignificant differences $(P>0.05)$ are indicated as NS. ${ }^{23-25,28}$

\section{Results}

\section{$\mathrm{PH}$ induces E2 concentration in orchiectomized and OVX mice}

Previous studies indicate that $\mathrm{PH}$ induces E2 concentration in human beings, rats, and male mice (Figure 1). ${ }^{9,11,12,20}$ E2 is converted from testosterone by aromatase, and the highest expression of aromatase is observed in the ovary and the testis; however, other tissues (eg, the gonads, placenta, adipose tissue, etc) also weakly produce aromatase. ${ }^{21,22}$ These observations suggested that no $\mathrm{PH}$-induced E2 production was observed in orchiectomized (ORC) mice. So, the male mice were operated with $\mathrm{ORC}$, and then, these ORC mice were operated with PH. After PH, plasmas were collected, and circulating E2 concentrations were measured (Figure 1A). Plasma E2 was strongly elevated after 6-48 hours in the control mice after PH (open squares) and was also induced after 24-48 hours in the ORC mice (filled triangles with dotted lines), which indicates that the $\mathrm{E} 2$ induction following $\mathrm{PH}$ was delayed and reduced in the ORC mice. $\mathrm{PH}$-induced E2 concentrations were mainly from testes (of control mice) and majorly from nontestes organs (of ORC mice, eg, gonads, adipose tissue; Figure $1 \mathrm{C}$ ).

Female mice have endogenous higher E2 concentration than male mice; so, OVXs were performed (Figure 1B) to analyze the effects of E2 concentration after PH. E2 concentrations
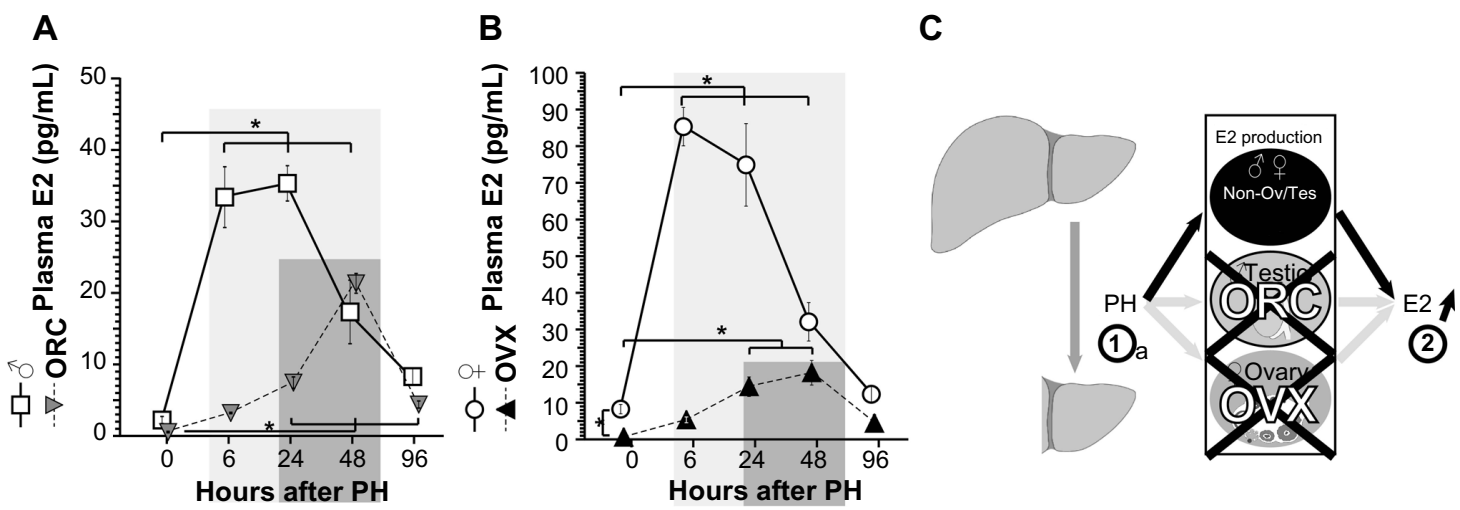

Figure I Delayed elevations of circulating E2 and ER $\alpha$ expression after PH were observed in the ORC and OVX mice.

Notes: (A and B) PH increased circulating E2 concentrations. Sham-operated control (male mice, A, open squares; female mice, B, open circles), ORC (A, gray inverted triangles with dotted lines), and the OVX (B, filled triangles with dotted lines) B6 mice underwent PH operations, and the concentrations of E2 were analyzed. The values are expressed as the mean $\pm \mathrm{SEM}(\mathrm{n}=5)$. ${ }^{*} \mathrm{P}<0.05$. (C) Possible model of the $\mathrm{PH}$-induced E2 production.

Abbreviations: E2, estradiol; ER $\alpha$, estrogen receptor $\alpha$; PH, partial hepatectomy; ORC, orchiectomy; OVX, ovariectomy; SEM, standard error of the mean. 
were significantly decreased in the OVX mice (Figure 1B). After PH, E2 concentrations were induced in both OVX and control females. The E2 peaks in control females were $\sim 80 \mathrm{pg}$ / $\mathrm{mL}$ after 6-48 hours, and those of OVX mice were $\sim 30 \mathrm{pg}$ / $\mathrm{mL}$ after 24-48 hours, indicating delayed and small $\mathrm{E} 2$ induction by OVX. Taken together, $\mathrm{PH}$ induced E2 concentration mainly from testes and ovaries, and partly and delayed from other organs (unknown) in Figure 1C. Taken together, this is the first observation where $\mathrm{PH}$ triggered E2 concentration in both ORC and OVX animals.

\section{E2 administration and the estrous cycle induced E2 concentration and hepatocyte proliferation}

PH induces E2 concentration ${ }^{9,11,12,20}$ (Figure 1) as well as hepatocyte proliferation (Figure 2). ${ }^{14,15}$ E2 was administered to the OVX mice, and hepatocyte proliferation was analyzed (Figure 2A). E2 administration induced hepatocyte proliferation in the OVX mice in a dose-dependent manner (Figure $2 \mathrm{~A}$ and $\mathrm{B}$ ). ${ }^{32}$ The target factors of $\mathrm{E} 2$ are ER $\alpha, \mathrm{ER} \beta$, and GPR30, ${ }^{3-6}$ and the ICI182780 (ICI) is one of the selective ER modulators (SERMs). ICI is an antagonist for ER $\alpha$ and ER $\beta$, but an agonist for GPR30. 5,6,33,34 ICI reduced hepatocyte proliferation (Figure 3B), which indicates that the target(s) of E2 action is related to hepatocyte proliferation that was not GPR30 but could have been ER $\alpha$ and/or ER $\beta$. Moreover, no ER $\beta$ expression was observed in the male livers. ${ }^{19,20}$

$\mathrm{E} 2$ is primarily produced by the ovaries in female mice. ${ }^{21,22}$ Generally, E2 production is dependent on the estrous cycle of nonpregnant mice, and E2 production is elevated during the proestrus period and reduced in the estrous cycle..$^{35,36}$
The estrous cycles, E2 concentrations, and hepatocyte proliferations of nonpregnant female mice were analyzed (Figure 2B). The peak E2 concentrations and hepatocyte proliferations occurred during the proestrus phase/period (Figure 2B). E2 was administered to the OVX mice, and E2 concentrations and hepatocyte proliferations were analyzed (Figure 2C). Both the E2 concentrations and hepatocyte proliferations were similarly elevated in an E2-dependent manner (Figure 2A). Taken together, both E2 administration and the estrous cycle induced E2 concentration and induced E2 concentration lead hepatocyte proliferation (Figure 2C).

\section{E2 and SERM administration regulated hepatocyte proliferation}

To access the target factor for hepatocyte proliferation, several SERMs were administrated to hepatocytes (Figure 3). At first, E2 (filled bar in Figure 3A) and ICI (ER $\alpha$ and $\beta$ antagonist, GPR30 agonist, gray bar in Figure 3A) were administrated to B6 WT mice (Figure 3A). E2-stimulated hepatocyte proliferation and ICI-inhibited hepatocyte proliferation indicated that hepatocyte proliferation was due to ER $\alpha$ and/or ER $\beta$, not due to GPR30 (Figure 3C). Other SERM, such as PPT (ER $\alpha$ specific agonist, triangles, CAS No: $263717-53-9)^{37}$ induced HepG2 cell proliferation significantly, but no induction was observed with ER $\beta$-specific agonist DPN (circles, CAS No: 1428-67-7), indicating that ER $\alpha$ is the E2 target factor for E2-induced hepatocyte proliferation (Figure 3C). Using $\mathrm{ER} \alpha$ and $\mathrm{ER} \beta$ knock out (KO) (and their control) mice, ${ }^{31}$ we confirmed that E2-induced hepatocyte proliferation was via $\mathrm{ER} \alpha$, not $\mathrm{ER} \beta$ (data not shown and manuscript in preparation). Moreover, hepatocyte-specific $\mathrm{ER} \alpha \mathrm{KO}$ mice ${ }^{23,27}$ were
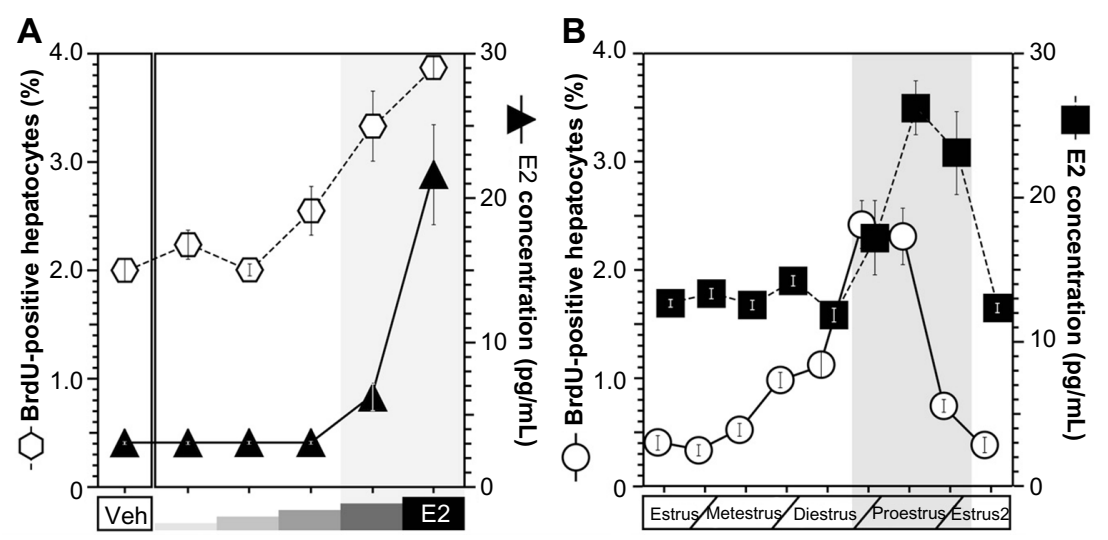

C

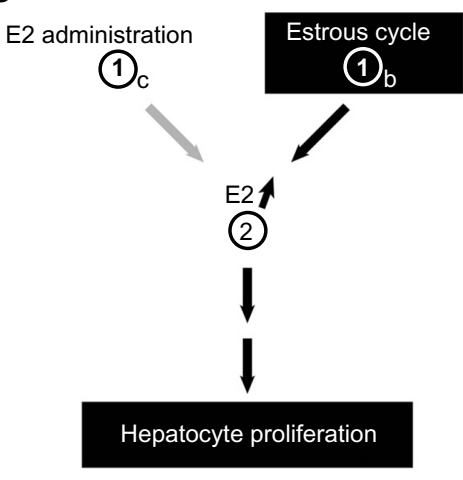

Figure 2 The estrous cycle regulated E2 concentration and hepatocyte proliferation.

Notes: (A) Both of hepatocyte proliferation (left $y$-axis, BrdU-positive hepatocytes, and the open hexagons with dotted lines) and the circulating concentration of E2 (right $y$-axis and the filled triangle) were increased in an E2 dose of 0 (Veh), I, 3, 10,30, and $100 \mathrm{mg} / 30 \mathrm{~g}$ body weight. The values are expressed as the mean $\pm S E M(n=5)$. *P $<0.05$. (B) The estrous cycle regulated E2 concentration (right $y$-axis and the filled rectangles) and hepatocyte proliferation (left $y$-axis, BrdU-positive hepatocytes, and the open circle). The values are expressed as the mean $\pm \operatorname{SEM}(n=5)$. ${ }^{*}<0.05$. (C) Possible model of the estrous cycle regulated hepatocyte proliferation.

Abbreviations: E2, estradiol; BrdU, bromodeoxyuridine; SEM, standard error of the mean. 
A

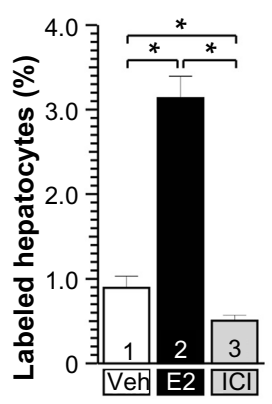

B

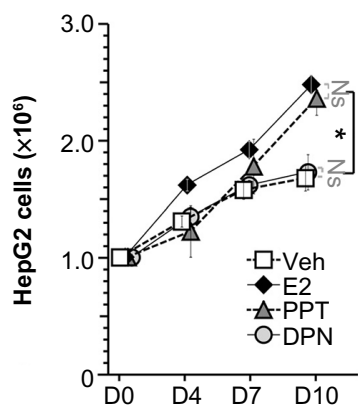

C

\begin{tabular}{l||c|c|c||c}
\multicolumn{1}{c||}{} & \multicolumn{3}{c||}{ Estrogen receptors } & \multirow{2}{*}{ Drugs } \\
\cline { 2 - 4 } & ER $\alpha$ & ER $\beta$ & GPR30 & Hep proliferat \\
\hline \hline E2 & Agonist & Agonist & Agonist & Agonist \\
ICI & Antagonist & Antagonist & Agonist & Antagonist \\
PPT & Agonist & No effect & No effect & Agonist \\
DPN & No effect & Agonist & No effect & No effect \\
& & & &
\end{tabular}

Figure 3 SERM administration regulated hepatocyte proliferation.

Notes: (A) E2 administration induced hepatocyte proliferation. Vehicle (column I, Veh, EtOH, open bar), E2 (column 2, black bar), or ICl (column 3, light gray bar) were injected at doses of $100 \mathrm{mg} / 30 \mathrm{~g}$ body weight. BrdU was injected, and the labeled hepatocytes were counted. The values are expressed as the mean $\pm S E M(n=7)$. $* P<0.05$. (B) DPN administration induced hepatocyte proliferation. Vehicle (open squares with dotted lines, Veh, EtOH), I $\mu$ M E2 (filled diamonds), I $\mu$ M PPT (dark gray triangles), and I $\mu$ M DPN (light gray circles with dotted lines) were administrated to Hep G2 cells, and the cell numbers were counted at Day 0 (D0), 4 (D4), 7 (D7), and I0 (DI0). (C) Summary of results of drugs in Figure $3 \mathrm{~A}$ and $3 \mathrm{~B}$. The values are expressed as the mean $\pm \operatorname{SEM}(\mathrm{n}=5)$. $* P<0.05$.

Abbreviations: SERM, selective estrogen receptor modulator; E2, estradiol; ICI, ICII82780; BrdU, bromodeoxyuridine; GPR, G protein-coupled receptor; ER $\alpha$, estrogen receptor $\alpha$; ER $\beta$, estrogen receptor $\beta$; SEM, standard error of the mean; DPN, 2,3-bis(4-hydroxyphenyl)propionitrile; PPT, 4,4',4'-(4-propyl-[IH]-pyrazole-I,3,5-triyl)trisphenol.

established and analyzed, resulting in similar results (data not shown and manuscript in preparation). Taken together, E2-induced hepatocyte proliferation might be via hepatocyte$\mathrm{ER} \alpha$ with ligand and receptor analyses.

\section{E2 administration and $\mathrm{PH}$ induced $\mathrm{ER} \alpha$ expression in periportal hepatocytes}

The mRNA expressions of ER $\alpha$ and ER $\beta$ in the liver were analyzed using reverse transcription polymerase chain reaction (RT-PCR) (Figure 4A) and in situ hybridization (Figure 4B). First, ER $\beta$ mRNA was detected in the positive control of ovary, and not amplified from liver samples (Figure 4A). ${ }^{19} \mathrm{PH}$ and E2 administration induced the transcripts of ER $\alpha$ (Figure 4A). Note that both E2 injection and $\mathrm{PH}$ induced ER $\alpha$ expression synergetically. Delayed induced expression of $\mathrm{ER} \alpha$ was observed in OVX mice at 24 hours after $\mathrm{PH}$, similar to delayed E2 induction in OVX mice (Figure 1B). These observations suggested that $\mathrm{PH}$ induced delayed E2 concentration and ER $\alpha$ expression.

Moreover, E2 and $\mathrm{PH}$ induced $\mathrm{ER} \alpha$ expression mainly in the hepatocytes located in the periportal area (Figure 4B), and these hepatocytes are known to actively proliferate after $\mathrm{PH}^{38}$

\section{Delayed hepatocyte proliferation after $\mathrm{PH}$ in OVX mice}

No significant differences in liver weight were observed between the OVX and control mice before or after $\mathrm{PH}$ (Figure 5A and B). Hepatocytes are the main parenchymal cells of the liver, and DNA from the recovered livers was extracted and analyzed. The liver DNA quantities were restored by 4 days after $\mathrm{PH}$ in the OVX and control mice, and no significant differences were observed between the OVX and control mice (Figure 5C); these findings indicate that OVX had no significant effect on the liver regeneration. Moreover, hepatocyte proliferation following PH was

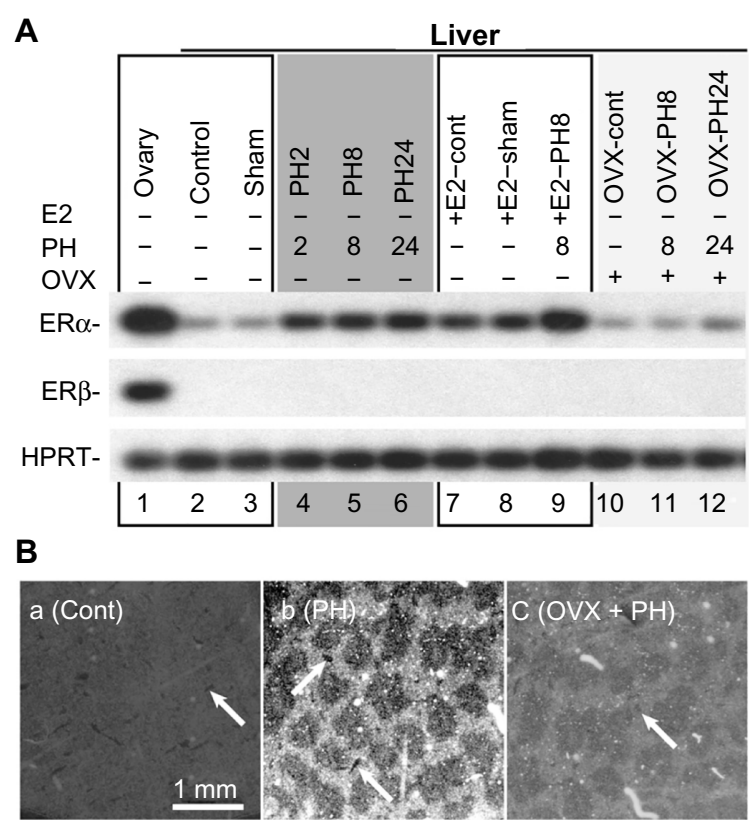

Figure $4 \mathrm{PH}$ induced $\mathrm{ER} \alpha$ expression in the hepatocyte of periportal area. Notes: $\mathrm{PH}$-stimulated $\mathrm{ER} \alpha$ expression in the periportal hepatocytes. After the $\mathrm{PH}$ operations, the livers were removed from these mice. ER $\alpha$ expression levels were analyzed with RT-PCR (A) and ISH (B). (A) The liver RNAs of the control (lanes 2, 7, and I0), PH (2-h lane 4, 8-h lanes 5, 9, and II, 24-h lanes 6 and I2), the E2-injected mice (lanes 7, 8, and 9), and OVX (lanes 10, II, and I2) were extracted, and RTPCR was performed. (B) The livers were removed from the control (a), the $\mathrm{PH}(\mathbf{b})$, and the OVX-PH (c) mice. ISH was performed using ER $\alpha$ probes. Scale bars =I mm. The white arrows indicated portal veins.

Abbreviations: $\mathrm{PH}$, partial hepatectomy; $\mathrm{ER} \alpha$, estrogen receptor $\alpha ; \mathrm{RT}-\mathrm{PCR}$, reverse transcription polymerase chain reaction; ISH, in situ hybridization; OVX, ovariectomy; E2, estradiol; HPRT, hypoxanthine-guanine phosphoribosyltransferase. 
A

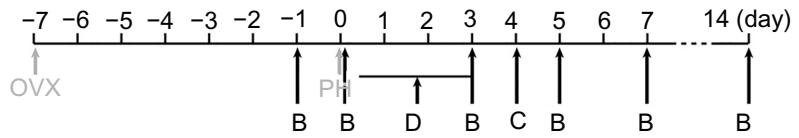

B
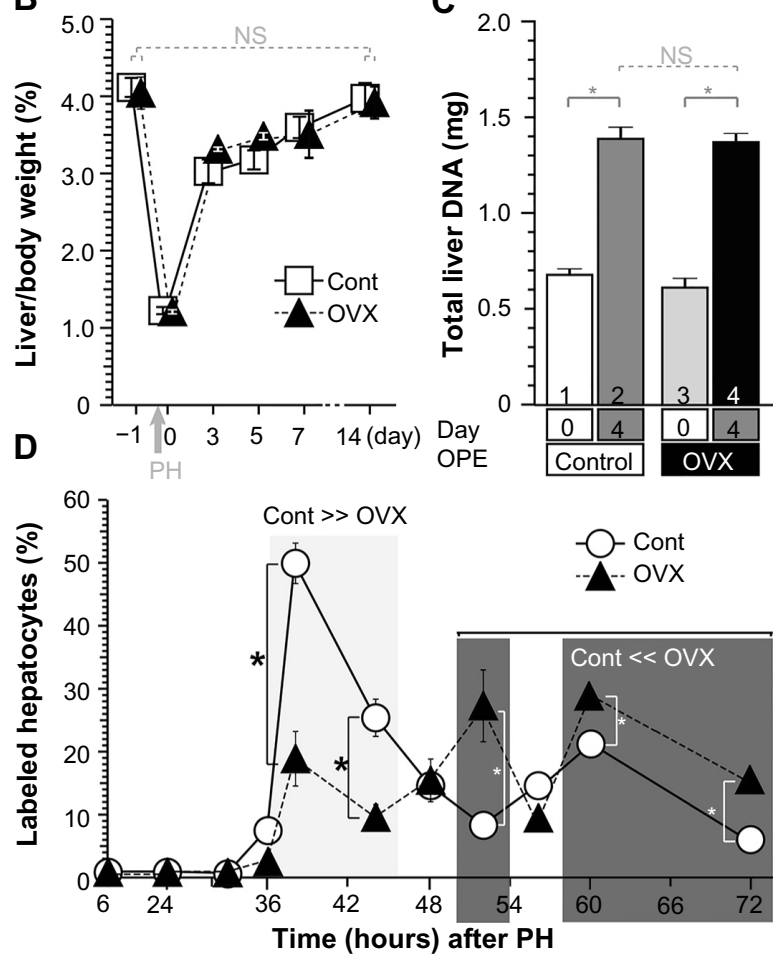

Figure $\mathbf{5}$ OVX did not affect liver weight recovery after $\mathrm{PH}$, and the hepatocyte proliferations were delayed.

Notes: (A) The time course of the OVXs and PHs are illustrated in B-D. (B and C) Control (Cont) and OVX B6 female mice underwent PH operations; the liver weight recovery (B) and hepatocyte proliferation were analyzed by $\mathrm{BrdU}-\mathrm{IHC}(\mathbf{C})$. The values are expressed as the mean \pm SEM $(n=5-9)$. $* P<0.05$. (D) The livers were prepared after $\mathrm{PH}$ at the indicated times, and the $\mathrm{BrdU}$-positive hepatocytes were counted. The values are expressed as the mean \pm SEM $(n=5-7) . * P<0.05$.

Abbreviations: OVX, ovariectomy; $\mathrm{PH}$, partial hepatectomy; $\mathrm{BrdU}-\mathrm{IHC}$, bromodeoxyuridine immunohistochemistry; SEM, standard error of the mean; NS, nonsignificant; OPE, operation.

analyzed based on BrdU incorporation. The rate of hepatocyte proliferation in the control mice was significantly elevated 36-44 hours after PH, but that of the OVX mice was significantly higher at 52 hours, and 60-72 hours after PH (Figure 5D). These data indicate that the OVX mice displayed slightly delayed hepatocyte proliferation (Figure 5D) but no significant change in liver weight/DNA amount recovery (Figure 5B and C).

\section{Discussion}

\section{$\mathrm{PH}$ induced increases in E2}

\section{concentrations in ORC and}

\section{OVX living organisms}

This is the first study that $\mathrm{PH}$ induced $\mathrm{E} 2$ production in ORC and OVX animals. In the papers in the 1970s and 1980s, and in our latest studies, no observation of $\mathrm{E} 2$ induction in $\mathrm{ORC} /$ OVX rodents or human beings was reported.

\section{$\mathrm{E} 2$ administration and $\mathrm{PH}$ induced $\mathrm{ER} \alpha$ expression in the livers of the}

\section{female mice}

The first ER $\alpha$ was cloned by Professor Pierre Chambon in 1986. The first Francavilla's study was published in 1984; they did not know the ER $\alpha$ itself. Recently ER $\alpha$ expression is induced in male mice, indicating that this is the first study to report ER $\alpha$ expression in females.

\section{Hepatocyte proliferation was also observed in the proestrus period of the estrous cycle}

There are no studies about hepatocyte proliferation in the estrous cycle, and this is the first case of hepatocyte proliferation that was observed in sex cycles of females.

\section{Conclusion}

The possible mechanisms of $\mathrm{PH}$ - and E2-induced hepatocyte proliferation were identified (Figure 6). PH (step 1a), the estrous cycle (step 1b), and E2 injection (step 1c) stimulated increases in E2 concentrations (step 2), ER $\alpha$ expression in the periportal hepatocytes (step 3), and hepatocyte proliferation.

\section{Future perspective \\ Genetical study}

Our previous and latest studies showed that PH induced ER $\alpha$ expression in rodents of both sexes. Using genetically modified mice disrupting ER genes, the hepatic ER function in liver regeneration was contributed (manuscript in preparation).

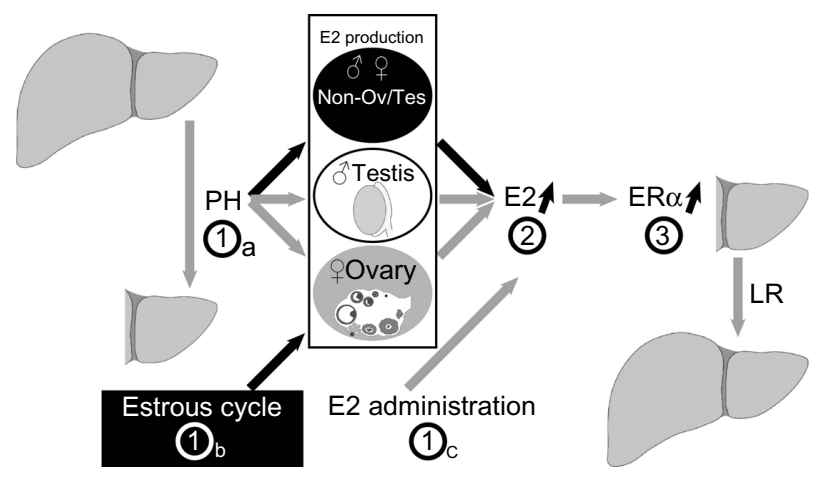

Figure $\mathbf{6}$ Model of hepatocyte proliferation in female mice.

Notes: PH (step Ia), the estrous cycle (step Ib), and E2 injection (step Ic) increased E2 concentrations (step 2), and ER $\alpha$ expression in the periportal hepatocytes was stimulated (step 3), which resulted in hepatocyte proliferation and LR.

Abbreviations: $\mathrm{PH}$, partial hepatectomy; E2, estradiol; $\mathrm{ER} \alpha$, estrogen receptor $\alpha$; $\mathrm{LR}$, liver regeneration. 


\section{During pregnancy}

We demonstrated that induced E2 production in the estrus period of the estrous cycle triggered hepatocyte proliferation. In general, when are the females exposed highest E2 concentration? It is during pregnancy. The livers during pregnancy were analyzed, and hepatocyte proliferation was observed as expected (manuscript in preparation).

\section{Acknowledgments}

We are grateful to our department members in the NCGG for helpful discussions. This work was supported by a grant-inaid from the Ministry of Education, Culture, Sports, Science and Technology (MEXT) and a grant from the Japan Science and Technology Agency (JST) to TI. The funders had no role in study design, data collection and analysis, the decision to publish, or manuscript preparation.

\section{Disclosure}

The authors report no conflicts of interest in this work.

\section{References}

1. Ciocca DR, Roig LM. Estrogen receptors in human nontarget tissues: biological and clinical implications. Endocr Rev. 1995;16(1): 35-62.

2. Couse JF, Korach KS. Estrogen receptor null mice: what have we learned and where will they lead us? Endocr Rev. 1999;20(3):358-417.

3. Antal MC, Petit-Demoulière B, Meziane H, Chambon P, Krust A. Estrogen dependent activation function of ER $\beta$ is essential for the sexual behavior of mouse females. Proc Natl Acad Sci U S A. 2012;109(48): 19822-19827.

4. Adlanmerini M, Solinhac R, Abot A, et al. Mutation of the palmitoylation site of estrogen receptor $\alpha$ in vivo reveals tissue-specific roles for membrane versus nuclear actions. Proc Natl Acad Sci U S A. 2014; 111(2):E283-E290.

5. Chimento A, Sirianni R, Casaburi I, Pezzi V. GPER signaling in spermatogenesis and testicular tumors. Front Endocrinol (Lausanne). 2014;30:5

6. Vaucher L, Funaro MG, Mehta A, et al. Activation of GPER-1 estradiol receptor downregulates production of testosterone in isolated rat Leydig cells and adult human testis. PLoS One. 2014;9:e92425.

7. Jensen EV, Jordan VC. The estrogen receptor: a model for molecular medicine. Clin Cancer Res. 2003;9(6):1980-1989.

8. Fisher B, Gunduz N, Saffer EA, Zheng S. Relation of estrogen and its receptor to rat liver growth and regeneration. Cancer Res. 1984;44(6): 2410-2415.

9. Francavilla A, Eagon PK, DiLeo A, et al. Sex hormone-related functions in regenerating male rat liver. Gastroenterology. 1986;91(5): 1263-1270.

10. Kahn D, Gavaler JS, Makowka L, et al. Does hyperprolactinemia affect hepatic regeneration independent of sex steroids? J Lab Clin Med. 1988;112(5):644-651.

11. Francavilla A, Polimeno L, DiLeo A, et al. The effect of estrogen and tamoxifen on hepatocyte proliferation in vivo and in vitro. Hepatology. 1984;9(4):614-620.

12. Francavilla A, Gavaler JS, Makowka L, et al. Estradiol and testosterone levels in patients undergoing partial hepatectomy. A possible signal for hepatic regeneration? Dig Dis Sci. 1989;34(6):818-822.

13. Kahn D, Eagon PK, Porter LE, et al. Effect of tamoxifen on hepatic regeneration in male rats. Dig Dis Sci. 1989;34(1):27-32.
14. Steer CJ. Liver regeneration. FASEB J. 1995;9(14):1396-1400.

15. Michalpoulos GK, DeFrances MC. Liver regeneration. Science. 1997;276(5309):60-66.

16. Kuiper GG, Carlsson B, Grandien K, et al. Comparison of the ligand binding specificity and transcript tissue distribution of estrogen receptors alpha and beta. Endocrinology. 1997;138(3):863-970.

17. Ciana P, Di Luccio G, Belcredito S, et al. Engineering of a mouse for the in vivo profiling of estrogen receptor activity. Mol Endocrinol. 2001;15(7):1104-1113.

18. Ciana $\mathrm{P}$, Raviscioni $\mathrm{M}$, Mussi $\mathrm{P}$, et al. In vivo imaging of transcriptionally active estrogen receptors. Nat Med. 2003;9(1):82-86.

19. Vacca M, D’Amore S, Graziano G, et al. Clustering nuclear receptors in liver regeneration identifies candidate modulators of hepatocyte proliferation and hepatocarcinoma. PLoS One. 2014;9:e104449.

20. Uebi T, Umeda M, Imai T. Estrogen induces estrogen receptor alpha expression and hepatocyte proliferation in the livers of the male mice. Genes Cells. 2015;20(3):217-223.

21. Carreau S, Lambard S, Delalande C, Denis-Galeraud I, Bilinska B, Bourguiba S. Aromatase expression and role of estrogens in male gonad: a review. Reprod Biol Endocrinol. 2003;1:35.

22. Bulun SE, Lin Z, Imir G, et al. Regulation of aromatase expression in estrogen-responsive breast and uterine disease: from bench to treatment. Pharmacol Rev. 2005;57(3):359-383.

23. Imai T, Jiang M, Kastner P, Chambon P, Metzger D. Selective ablation of retinoid $X$ receptor alpha in hepatocytes impairs their lifespan and regenerative capacity. Proc Natl Acad Sci U S A. 2001;98(8):4581-4586.

24. Imai T, Takakuwa $\mathrm{R}$, Marchand $\mathrm{S}$, et al. Peroxisome proliferatorsactivated receptor $\gamma$ is required in mature white and brown adipocytes for their survival in the mouse. Proc Natl Acad Sci USA. 2004;101(13): 4543-4547.

25. Umeda M, Uebi T, Maekawa N, Handa H, Imai T. PGJIFs, new mitochondrial PGJ2 target proteins, regulate cell proliferation. J Biosci Med. 2013;1(3):11-15.

26. Dollé P, Duboule D. Two gene members of the murine HOX-5 complex show regional and cell-type specific expression in developing limbs and gonads. EMBO J. 1989;8(5):1507-1515.

27. Imai T, Chambon P, Metzger D. Inducible site-specific somatic mutagenesis in mouse hepatocytes. Genesis. 2000;26(2):147-148.

28. Imai T, Jiang M, Chambon P, Metzger D. Impaired adipogenesis and lipolysis in the mouse upon Cre-ER ${ }^{\mathrm{T} 2}$-mediated selective ablation of RXR alpha in adipocytes. Proc Natl Acad Sci U S A. 2001;98(1): 224-228.

29. Niederreither K, Fraulob V, Garnier JM, Chambon P, Dollé P. Differential expression of retinoic acid-synthesizing (RALDH) enzymes during fetal development and organ differentiation in the mouse. Mech Dev. 2002;110(1-2):165-171.

30. Imai T, Matsuda K, Shimojima T, et al. ERC-55, a binding protein for the papiloma virus E6 oncoprotein, specifically interacts with vitamin D receptor among nuclear receptors. Biochem Biophys Res Commun. 1997;233(3):765-769.

31. Dupont S, Krust A, Gansmuller A, Dierich A, Chambon P, Mark M. Effect of single and compound knockouts of estrogen receptors alpha (ERalpha) and beta (ERbeta) on mouse reproductive phenotypes. Development. 2000;127(19):4277-4291.

32. Higgins GM, Anderson RM. Experimental pathology of the liver I. Restoration of the liver of the white rat following partial surgical removal. Arch Pathol. 1931;12:186-202.

33. Dauvois S, White R, Parker MG. The antiestrogen ICI 182780 disrupts estrogen receptor nucleocytoplasmic shuttling. J Cell Sci. 1993;106(4): 1377-1388

34. Movérare-Skrtic S, Börjesson AE, Farman HH, et al. The estrogen receptor antagonist ICI 182,780 can act both as an agonist and an inverse agonist when estrogen receptor $\alpha \mathrm{AF}-2$ is modified. Proc Natl Acad Sci US A. 2014;111(3):1180-1185.

35. Blendinger K. Physiology and pathology of the estrous cycle of the bitch. Italian Companion Animal Veterinary Association. In: Proceedings of the SCIVAC Congress, Rimini, Italy; 2007:73-77. 
36. Santmyire BR, Venkat V, Beinder E, Baylis C. Impact of the estrus cycle and reduction in estrogen levels with aromatase inhibition, on renal function and nitric oxide activity in female rats. Steroids. 2010;75(12): 1011-1015.

37. Kitamura N, Araya R, Kudoh M, et al. Beneficial effects of estrogen in a mouse model of cerebrovascular insufficiency. PLoS One. 2009; 4(4):e5159.
38. Ferri D, Moro L, Mastrodonato M, et al. Ultrastructural zonal heterogeneity of hepatocytes and mitochondria within the hepatic acinus during liver regeneration after partial hepatectomy. Biol Cell. 2005;97(4): $277-288$.

\section{Publish your work in this journal}

Clinical and Experimental Gastroenterology is an international, peerreviewed, open access journal, publishing all aspects of gastroenterology in the clinic and laboratory, including: Pathology, pathophysiology of gastrointestinal disease; Investigation and treatment of gastointestinal disease; Pharmacology of drugs used in the alimentary tract;
Immunology/genetics/genomics related to gastrointestinal disease. This journal is indexed on CAS. The manuscript management system is completely online and includes a very quick and fair peer-review system. Visit http://www.dovepress.com/testimonials.php to read real quotes from published authors.

Submit your manuscript here: http://www.dovepress.com/clinical-and-experimental-gastroenterology-journal 